\title{
ROLE OF TOUR OPERATORS AND TRAVEL AGENGIES IN PROMOTING SUSTAINABLE TOURISM
}

\author{
Andreea Marin-Pantelescu ${ }^{1 *}$, Laurențiu Tăchiciu ${ }^{2}$, Sorinel Căpușneanu ${ }^{3}$ \\ and Dan Ioan Topor ${ }^{4}$ \\ ${ }^{112)}$ Bucharest University of Economic Studies, Romania \\ ${ }^{3)}$ Dimitrie Cantemir Christian University, Bucharest, Romania \\ 4)1 Decembrie 1918 University, Alba-Iulia, Romania
}

\begin{abstract}
Please cite this article as:
Marin-Pantelescu, A., Tăchiciu, L., Căpușneanu, S. and

Topor, D.I., 2019. Role of Tour Operators and Travel

Agencies in Promoting Sustainable Tourism. Amfiteatru

Economic, 21(52), pp. 654-669.
\end{abstract}

DOI: $10.24818 / \mathrm{EA} / 2019 / 52 / 654$

\begin{abstract}
Due to its relative contribution and growing impact in the economy, tourism can play an important role in advancing the universal 2030 Agenda for Sustainable Development, including the application of bioeconomy principles, when governed with social responsibility, following sector specific standards as the ones provided by the Global Sustainable Tourism Council. In consideration of their privileged position within the tourism supply chain the study focusses on tour operators attempting to capture their current efforts toward social responsibility and the degree to which their activities comply with the applicable criteria for sustainable tourism. For three of the most important Romanian tour operators, the study provides an inventory of concrete ongoing activities and organizational governing principles in force which demonstrates a fairly high commitment toward social responsibility. However, companies recognise that such commitment it seeks to strengthen the corporate image rather than more fundamental sustainability goals. Among respondents, awareness of social responsibility principles and themes is higher than the awareness about specific sustainable tourism criteria. Moreover, the accent falls on the organization in question and only incidentally other supply chain links are involved. Further efforts have to be deployed in order to systematically implement the relevant sustainable tourism code, but companies manifest concern about the financial outcomes of such an investment.
\end{abstract}

Keywords: Corporate Social Responsibility (CSR), sustainable management, tour operators and travel agencies, Global Sustainable Tourism Council (GSTC) Code.

JEL Classification: D83, M14, Q53

\footnotetext{
* Corresponding author, Andreea Marin-Pantelescu - marindeea@ yahoo.com
} 


\section{Introduction}

The shift toward a more sustainable economy pattern, including application of bio-economy and circular economy concepts and related principles and processes, require changes in the set of economic incentives and adjusting of interdependencies between economic sectors. The increasing economy wide impact of tourism justify the assumption that tourism value chains can play a significant role in paving the way for the transition to bioeconomy.

Recent data published by World Travel \&Tourism Council (WTTC) estimate at $3.2 \%$ the direct contribution of tourism to the world GDP in 2018, and at $10.4 \%$ its overall economic impact (cumulating direct, indirect and induced economic effects). Tourism is expected to grow faster than the average global economic grow, with 3.6 per annuum in the next decade. It means that the importance of tourism in the economy is expected to become even higher in the future (WTTC, 2019).

On the other hand, the concept of bioeconomy is considered to bear at least three different meanings. Through a professionally conducted bibliometric analysis Bugge, Hansen and Klitkouhave (2016) found that the term bioeconomy is used by some authors with strict reference to biotechnology, by some other authors with an accent on bio-resources valorisation, while a part of the literature gives to the term the meaning of bioecology. In this last conception, bioeconomy encompasses sustainability, biodiversity, conservation of ecosystems and promotes integrated production systems with territorial identity. This is the meaning embraced by the authors of the present paper, as well.

The role of tourism in achieving Sustainable Development Goals (SDGs) was emphasised by the United Nations by declaring 2017 as the UN International Year of Sustainable Tourism for Development. "The underlying rationale for linking three SDG targets with tourism development objectives is based on the intrinsic local character of tourism activities, as tourism is driven by the attractiveness of local communities (culture, heritage) and the environment (natural assets and facilities)." (OECD, 2018).

The present paper undertakes an investigation of Corporate Social Responsibility (CSR) practices in tour operator and travel agencies in Romania, against the Global Sustainable Tourism Council (GSTC) Code. This approach is motivated by several aspects:

- first, by the observation that Romanian tour operators deploy significant efforts to improve their organizations behaviour in line with social responsibility principles;

- second, by the fact that tour operators - because of their position within the tourism supply chain - can play an important role in promoting sustainable practices both upstream, toward suppliers and downstream, toward tourists;

- third, by the assumption that formal explicit implementation of GSTC Code can speed up the transition to more sustainable business models in tourism, by comprehensive and systematic integration of sustainability criteria in every decision-making process.

The paper is organized as follows: the first section provides a review of the relevant literature, the second present the research methodology, then results are presented and discussed. Finally, we draw the conclusions. 


\section{Review of the literature}

Tourism can simply be defined as the movement of people outside the borders of their current residence, for leisure tourism or business tourism, but not for a longer period than 12 consecutive months (Wearne\&Baker, 2002). Similarly, tourism involves a series of diverse activities carried out at the tourism destination (including visiting relatives or friends, shopping or one-day city tours). According to Holloway (2012) defining tourism with precision is an impossible task. From his perspective (like a truth being told as a joke) the definition of a tourist is someone that travels to seek something different, and afterward complains about coming across things in a manner that was not expected.

The relationship between the suppliers of tourism services (transport, hotels, restaurants, entertainers) and tourists is an intermediary (most of the time) coming from tour operators (the creators of tourism packages) and the retail travel agencies (which sell the tourism products created by tour operators for a commission).

A tourism package usually includes air transport, accommodation, transport services from the airport to the hotel and back. Tour operators purchase beforehand a large range of services, for example airplane seats from different airline companies, hotel rooms, and other facilities regarding transfers from/to hotels or airports (Marin-Pantelescu, 2009). Tour operators buy in bulk and then sell the created tourism packages individually. Travel agencies handle all types of travel such as holiday and business travel on individual or group based.

Corporate Social Responsibility (CSR) also known as corporate sustainability, represents an approach of managing and running businesses with the conformity of protecting the environment, and sustaining it for the future generations, with a policy of not discriminating the employees, being involved in social projects, and prioritizing the common wellbeing of communities over profitability.

Starting as a business strategy, the effects of CSR have spread to a large extent of the society, so from internal voluntary decisions within organizations to binding rules and mandatory norms have only been one step.

Within companies, CSR represents an organizational policy, which follows a business strategy with ethical objectives. The business strategy aims to increase the trust of the customers and shareholders of the company by conducting activities based on ethical standards.

Power et al., (2017) assess in their research paper what does is mean an ethical behaviour in tourism industry? The answer was care, responsibility, altruism, humility, long term orientation, friendly clients' relationships, stakeholders' respect, and environment engagement.

As a response of the tourism community to the global challenges of the United Nations' Millennium Development Goals, a set of Global Sustainable Tourism Criteria has been adopted, aiming at effective sustainability planning, maximizing social and economic benefits for the local community, enhancing cultural heritage, maximizing environmental benefits and reducing the negative impact.

Addressing sustainable tourism goes hand in hand with putting social responsibility at the core of business strategies which in turn requires adequate economic incentives. Within the European Union, creating a framework to boost companies' ability to adopt socially 
responsible and sustainable practices is an ongoing concern for many years now (Dahlsrud, 2008). An important measure is the requirement that large enterprises disclose non-financial and diversity information (DIRECTIVE 2014/95/EU). Another illustration of this policy concern at EU level is the Sustainable Finance initiative.

Within this framework the question is how the tourism services supply chain works to conciliate economic and financial goals with an ethical behaviour and responsibility which touches all particularities from business to relations with employees, clients, shareholders, suppliers, environment and the local communities (European Commission, 2011 ).

From all the studies dedicated to Corporate Social Responsibility, some of them identified the importance of employee involvement in CSR initiatives and argue that market intelligence about the CSR strategy of the company draws consumers to it (Budeanu, 2005; Tepelus, 2005). Other researches state that CSR activities tend to be fragmented and uncoordinated which leads to impediments in measuring and quantifying them in company budgets (Sheldon and Park, 2011). As the tourism industry is heterogeneous and diversified, it becomes even more difficult to identify and coordinate the activities which are taking into account the development of responsible tourism (Levy and Park, 2011). In the work of Wells et al (2016) it is emphasized that CSR can be a strategic direction to ensure the long-term success of the company. Success presupposes the alignment of the program CSR to values, norms and mission organizes and their deep integration into the company's management practice. Van Wijk and Persoon; Tencati (2006) investigated the relationship between CSR activities and the size of firms. Multinational companies tend to be actively and deeply involved in CSR activities more than small and medium-sized firms and small and mediumsized firms (with less than 250 employees) tend to follow leaders in their field of activity. Practically, multinationals are a model for small and medium-sized companies to pursue CSR practices and actions. The flow of information between consumers and tour operators is intersected by travel agencies that distribute holiday packages. In order to prevent consumers from not having information about tourism products before visiting their holiday destination, travel agencies can inform consumers and also prepare and educate them. According to Nicolau (2008), the consumers' knowledge about the CSR activities carried out by the travel agency contributes to increasing consumer confidence. They become more receptive and more attached to the travel agency, believe in what it conveys and form a lasting relationship with it. In principle, supporting a few CSR actions is an easy thing to do, but constituting a sustainability strategy with a planned budget is something that involves knowledge, dedication and a lot of work (Jucan and Dolf, 2012). Most tour operator studies have been undertaken in Europe where their activities are more intensive (TUI, Thomas Cook, Kuoni), recognizing the critical role that they play in the sustainability of tourist destinations (Miller 2001; Kalisch 2002). Carey, Gountas, and Gilbert (1997), for ex-ample, compared the characteristics of general tour operators with those of UK specialists. They have demonstrated that specialized tourism agencies are more commit-ted to sustainability practices and create tourist packages to support sustainable development, and always have in mind the need for continued education and training in the spirit of responsible tourism. Van Wijk and Persoon (2006) in a tourism survey using a sample of 42 tour operators from the UK, Germany and the Netherlands found that tour operators publish numerous reports on CSR activities more than other companies that are part of the tourism industry. According to Fatma et al. (2016) TOs have understood the importance of sustainability and their ability to follow a correct attitude in running their supply chain, business operation and procedure of management demands, creating long-term positive effects on both corporations and their 
society. When local community needs grow due to a disaster, companies' CSR activities are intensifying (Supanti and Butcher, 2018). It creates "crisis cells", and each company, according to its own financial powers, helps the local community overcome the disaster. For the future, CSR may be a new business standard demanded by the society, and in order to be well-rated by customers and suppliers, travel agencies will have to practice CSR. Theodoulidis at el., 2017, demonstrates that there is a direct and strong link between corporate social responsibility (CSR) and corporate financial performance (CFP) for companies operating in the tourism industry.

In their paper Rethinking sustainability in the tour-operating industry: Worldwide survey of current attitudes and behaviours, the authors Goffi et al. (2018) propose developing a new approach to sustainability in tour operators (TO) sector by introducing sustainable corporate strategies. Thus, TOs maintain their economic capital and at the same time preserve their natural and social capital. The strategy of 'low price-high volumes-local exploitation' adopted by many traditional TOs is now antiquated, as a new vision blooms ensuring excellence in sustainability practices. The involvement of TOs in corporate social initiatives was determined by the consumers' pressures, which want to buy tourist packages from companies dedicated to the protection of tourist attractions. Also, nowadays consumers are concern about the environment and the welfare of the local community visited. They prefer to buy local souvenirs with the primary objective of increasing the local community revenues. Small TOs specialize in conserving nature and TOs specialize in cultivating the traditions of tourist destinations have high sustainability commitment, whereas generalist TOs show a lower degree of engagement in sustainability (Goffi et al., 2018).

However, there is need for more empirical investigation and assessment of the inter-action between the different supply chain links, especially with regard to the potentially important role of travel agencies in aligning the entire supply chain toward socially responsible and sustainable practices.

\section{Research methodology}

Our qualitative research through the direct interview method involved contacting and setting interviews at the tour operators' premises, with duration of 1 hour and 45 minutes. The following tour operators were contacted by email for interviews: Christian Tour, Eximtur, Paralela 45, Happy Tour, Vola.ro, Cocktail Holidays and Eurolines. Christian Tour, Eximtur and Paralela 45 responded promptly to our request and set interviews, Happy Tour through Executive Assistant to CEO Mihaela Milea wrote that at this time they are not involved in social responsibility projects, Vola.ro through Head of Marketing Claudia Tocila noted that they are OTA (Over-the-Air programming) and are not involved in social responsibility projects, Cocktail Holidays and Eurolines did not respond to the email and have no official views on social responsibility projects. During June-July, interviews were conducted at the Tour Operators' headquarters: Christian Tour, Eximtur and Paralela 45. The delegated persons were Christian Tour Director Raluca Hatmanu, PR \& Communication Eximtur Director Mihaela Drăghici and Paralela 45 Marketing Manager Dan Dumitru. The interview guide was based on the fact that people associate social responsibility as a component of the marketing and communication department (image).

The Global Sustainable Tourism Council (GSTC) Criteria have been created to provide a common understanding of the concept of "sustainable tourism" and are a set of minimum 
criteria that are recommended to be met by those aspiring to develop sustainable tourism activities. The criteria were organized on four distinct themes: sustainable planning, maximizing the economic and social benefits for employees and the local community, preserving cultural attractions and reducing the negative environmental impact. We started from the idea that Romanian tour operators who are financially strong (in terms of volume of sales, turnover, profit) are those who carry out activities related to the sphere of social responsibility.

\section{Results and discussions}

The analysis of the information obtained during the interviews with the responsible social responsibility policy of the three major tour operators for the Romanian industry was made in line with the four sets of criteria for sustainable tourism promoted by the Global Sustainable Tourism Council, as shown in the section devoted to research methodology.

\section{GSTC Section A - Demonstrate effective sustainable management}

The first set of criteria refers to the existence of a management system capable of integrating sustainability issues, identifying issues and risks associated with the organization's activities, formulating objectives, and mobilizing staff and business partners to achieve their goals, anticipating and preventing crisis situations and triggering a prompt response to unforeseen events. In this context, the major concern aims prudent financial management, this concern being justified by a suite of bankruptcy of travel agencies, which have caused significant damage to customers in recent years and have shaken public confidence in the Romanian tourism industry.

From the information provided by the interlocutors, it follows that all three companies have implemented complex management systems with detailed procedure manuals. These are supported by IT systems that provide real-time reports and detailed analyses needed to substantiate decisions. The emphasis is on the financial performance analysis, the value of sales per destination, the average package price, the number of airplane tickets sold by the agency, up to the volume sold by resellers, the overall performance of the company; it also generates operational reports per destination.

At the same time, companies have carried out Physical Security Risk Analysis and have taken all the safety and security measures of all employees and customers entering the travel agencies. GDPR (General Data Protection Regulation) has been massively invested in and specialist training has been carried out for all employees.

The Christian Tour representative evokes the way climate-specific issues are handled. The production section, which thinks and carries out tourist circuits in exotic areas (mainly in the Asian and the Far East) allocates in the planning of the holiday those periods in the calendar where the temperature is suitable for a pleasant stay, bearable temperatures, low humidity, bypass rainy season (see monsoons). For tourists to be protected from hot temperatures, these stays start from mid-September to April.

All three companies constantly oversee the security conditions for the destinations included in their offer with regard to various other categories of risk, such as political instability, terrorism, extreme weather phenomena, volcanic eruptions, etc., taking prompt action to avoid or limit potential harm to both clients and their own businesses. There is an IT 
application used by all tour operators for early warning of the occurrence of risk situations and there is a cooperative practice between tour operators in crisis situations. Travel agencies recommend that the tourist product is purchased from a specialist who has access to the area, can provide safety and protection in case of major risks because you need a group attendant, a Romanian speaking guide and local guide, often armed guard (for destinations like Egypt, Israel, Mexico).

Surveyed tour operators are aware of the problems caused by the bankruptcy of the cruise tour operators Mareea, Omnia Turism, or the travel agencies Terra Tour Holidays and Genius Travel. There has been need for congratulatory mobilization on the part of travel agencies, voluntarily, by creating so-called "crisis cells". Both Paralela 45, Eximtur and Christian Tour have helped to assist tourists in difficulty. Tourists staying in tourist resorts in hard-to-reach destinations were brought home safely free of charge by relocating Paralela 45 and Christian Tour aircraft. In some cases, vacationers were compensated for the full cost of their stay. According to the Paralela 45 representative, this is possible for own products resold by bankruptcy agents who do not pay for travel package services but only for "dozens of tourists". Most clients, however, have lost all the money paid in advance to the agencies that went bankrupt. The current holiday package guarantee system includes a \$50,000 insolvency policy for a tour operator and $\$ 10,000$ for a retailer travel agency. These insured amounts are insufficient to cover advances received from customers. European Directive 2302/2015 on the guarantee of tourist packages is being transposed in Romania, but tour operators are worried about how this legislation will affect the accessibility and competitiveness of their products. Regarding the way of application, ANAT (National Association of Tourism Agencies) and FPTR (Federation of Romanian Employers' Associations) have proposed several working variants and are trying to harmonize them. The proposal from tour operator Paralela 45 is to create additional (reinsurance) guarantee bodies.

According to our interlocutors, bankruptcy is the expression of ignorance of the business model. Although the impact on public awareness is strong, across the industry, the number of bankruptcies is relatively small ( 6 bankruptcies in an industry of more than 2500 firms). They believe that most companies show professionalism, the best assurance being given by a responsible and prudent management system. The Christian Tour Representative mentions the importance of rigorous planning: "In November-December 2018 the business plan is set for 2019. First, the destinations are selected; secondly for each destination the objectives are set: the number of tourists the agency wants and the value of the forecast sales. Thirdly, the local partners are contacted, and they tell them how many hotels they need to have guaranteed seats in the hotels they identify. It is desirable to attract tourists through a correct and transparent approach by presenting the necessary information for travel, transport, accommodation, guide services, and ensuring the safety of the tourist. It also takes account of unforeseen events (climate conditions, weather, political issues, and security in the area)". In the same sense, the Paralela 45 representative mentions rigorous "budgetary planning", and Eximtur recalls "strengthening a reputation based on earnestness and accountability".

All three interviewed companies are licensed to travel and are largely concerned to ensure compliance with current legislation, both in the country and in the countries of destination. A great deal in this regard is noted in the interview with the Eximtur representative. He goes on to say that the firm ensures the transparency of all financial operations, including the payment of salaries, as well as the payment of all taxes, fees and contributions according to the law. 
Other important elements of the management system that were highlighted by the interlocutors include the commitment of staff and business partners along the supply chain, customer quality and satisfaction management, transparency of public information, informing and educating tourists.

Companies carefully select staff with regard to basic training (studies and eventual tourism experience), seriousness and integrity. The staff is committed to applying the company's strategy, policies and procedures, being evaluated and rewarded fairly by results. Employees of Paralela 45, Eximtur or Christian Tour are sent to specialty courses, company information, with 2-3 'info-trips' per year for each employee. On these info-trips, they visit hotels and destinations with observation sheets, followed by analyses and synthesis observations. Documenting on the spot with your experience, knowing the realities on the spot (where the beach is, what the hotel room looks like, what breakfasts are available, how you interact with the locals, etc.) con-tributes both to increasing the capacity of the staff in relation to suppliers and customers, as well as highlighting and correcting potential shortcomings.

Paralela 45 has a strong focus on motivating and retaining staff. The company focuses on creating a friendly work environment, organizing 3 annual meetings with employees, presenting financial results, improving what is going on, which destinations are not good, what goes well as team building, and people want to work for Paralela 45. There are internal procedures grids, rewards for loyalty to the company through Fidelity Star program after 3 years, 5 years, 10 years, 15 years, 20 years, 25 years because the agency of tourism has 25 year-old employees in the company and people retiring from the company. Re-compensation is material but also emotional: a trophy is provided in a presentation with all the team working (this helps to increase self-esteem, you feel appreciated, desired, and useful and respected). After one year of seniority in the Paralela 45 travel agency, significant discounts are granted for family vacations. There is a great emphasis on the employees' family, June 1st, Easter, Christmas parties are organized for these, and gifts are shared. All these employee motivation systems make staff retention at Paralela 45 to be very, very large. This tells a lot about how valuable the employees are for the company.

Christian Tour organizes social events with business partners from various hotels with whom they have contracts. At each end of the summer season, TO organizes a party to enjoy with their partners. Partner hotels are searched for by TO according to tourists' preferences. Hotel partners are invited to the TTR with a stand provided by TO Christian Tour for them to present their host. At the TTR 2018 edition, 15 Christian Tour partners were invited from the following countries: Turkey, Egypt, India, etc. Juniors, agents who sell Christian Tour holidays at the beginning go on these info trips. Every year, Christian Tour organizes Spring School for the best vacation pack-age resellers. Representatives of partner agencies that are offered free marketing, communication, psychology, consumer behaviour, and art of sale courses are invited to attend. Through the social events created by TO Christian Tour, they focus on interpersonal relationships, and cultivate team spirit and friendship.

Eximtur has set up a tourism school that has trained up to 600 people to date. Exim-tur agency's quarterly magazine reported what happened most importantly in the agency. Recently, 10 competitions were registered at the level of the foreign tourism department. The winners were rewarded with holidays for their sales. Communication is highly appreciated, and the most important values for Eximtur are respect for customers, suppliers, employees and competition. More than that, Eximtur focuses on the initial training of new hired staff, which can be for several months. The company assumes the full cost of this process: 
transport, accommodation, food, and paid salary. All these efforts to have well-trained employees to meet the high standards that Eximtur promotes in order to ensure maximum customer satisfaction.

Care for the tourist is an essential preoccupation for all interviewed tour operators and part of sustainable management. All customers are treated equally and the main objective of the travel agency is customer satisfaction. Great emphasis is placed on this aspect of full tourist satisfaction. Special emphasis is placed on customer information as accurate as possible. Paralela 45 was among the first tour operator to implement "total package price transparency". They included in the price displayed in the headquarters and brochures the final price which included all services plus airport taxes, and all taxes. Later, this practice has become generalized within the industry.

The partners with whom Christian Tour, Eximtur or Paralela 45 collaborate are supervised as an image and checked for fairness. Information systems allow managing complaints from tourists and, if they are entitled to them, tour operators compensate tourists with upgrades for additional accommodation and services.

Customer satisfaction with Paralela 45 is so high that over $35 \%$ of all customers are repetitive tourists. Although it is not a $100 \%$ economically viable business, Paralela 45 has in all destinations where it operates a local agent, or a Paralela 45 employee, or a local representative of another local tour operator with whom it is linked permanently, which is a valued thing from the perspective of the tourist.

Tour operators in Romania admit that at this moment they do not make a selection of service providers according to criteria that explicitly mean sustainability. This has not yet been achieved, because on the one hand they are working in real time with thousands of integrated hotels and on the other hand they cannot afford it to be so selective. Being thousands of hotels, they are dynamic, they change their owners, their name, they make acquisitions, transformations and so it is difficult to make a selection of suppliers on the basis of sustainability. Moreover, there is no relevant percentage of hotels, Paralela 45, Eximtur or Christian Tour areas that are marked as meeting GSTC or "environment-friendly".

There is still no pressure on the Romanian market even from tourists for sustainable holiday packages. We do not have pretentious tourists yet pursuing the sustainability criteria. It will be the tour operator's role to provide education in this regard. Concerns for tourists to benefit from sustainable tourism products are at an early stage, so no Tour Operator has ever experienced any pressure from tourists or an interest in such vacation packages.

\section{GSTC Section B - Maximize social and economic benefits to the local community and minimize negative impacts}

The second set of criteria for sustainable tourism addresses the policies, procedures and measures by which tour operators must ensure that the negative impact on local communities is minimized and that community benefits are maximized. The criteria in this section refer to "where the tour operator is particularly active", which indicates both communities in which their own staff and tourist destination communities work.

The community support programs of the interviewed tour operators target especially vulnerable groups in Romania and are in harmony with the policies of consolidating a favourable company image and promoting their own products. 
Paralela 45 performs the "First Day at the Seaside" program every year. The idea of the campaign came as a result of highlighting in the public environment that $22 \%$ of Romanians had never been at the seaside, according to an IRES study, while another, conducted by World Vision Romania and Babeş-Bolyai University in Cluj Napoca, shows that half of the children in Romania are at risk of poverty and social exclusion.

The first edition took place between May 31 and June 4, 2017 at the Delta Hotel in Jupiter where 36 children from Ploieşti (from the children's homes of the Concorde Humanitarian Organization) saw the sea for the first time. In the first edition, Paralela 45 fully supported the humanitarian project; the idea involved significant logistical, financial and legal investment. The program well thought out and structured properly, as only a traditional tour operator could do, consisted of several activities, including the Constanta Dolphinarium, the interaction of Black Sea Cops, guided by a saviour, Tomis Harbor, Aquarium and Ferma Animalelor Ograda Veseliei in Mangalia.

The second edition took place between 21-24 June 2018 in Eforie Nord, where 21 children under the Concordia Humanitarian Organization enjoyed the beach, the sea and many fun activities. At the second edition, Tour operator Paralela 45 joined Subway Bucharest, Subway Constanta, Romanian researchers through Marini Research Center and Eforie Aqua Park, which together provided facilities and activities for children. Thus, the Tour Operator served as an example for the other companies, being the "engine" that put things in motion with the other sponsors coming with an open heart. The selection criterion will remain the same for next year for the "First Day at Sea" campaign, namely "children who have never seen the sea".

"First Day at Sea" is the most important social responsibility campaign run by the Tour Operator Paralela 45. Paralela 45 Tour Operator's CSR actions focus on education, disadvantaged children, environmental protection and cultural activities.

Tour operator Christian Tour founded the Christian Hope Foundation. The Christian Hope Foundation has been working for over 18 years and is involved in projects to support children born in the most precarious environments. Basically, Christian Hope aims to change the destiny of needy people for the better, and give children a chance to live, to education, to a decent life.

The Christian Hope Foundation has 2 Centres in Dărăşti and Vlașca, both in Adunații Copăceni, Giurgiu County. For children hosted here, they offer children a hot meal and holidays in the country. It is worth mentioning the annual humanitarian campaigns by organizing camps for children at the seaside, in the mountains and in Bucharest. The Christian Tour aims to give the local community something more, to give joyful holidays to people through investment projects in localities.

The Christian Hope Foundation recently hosted 30 children from the centres that the foundation administers. These children had never been to the mountains. The joy was immense. The tourism program offered included mountain trekking to the Susai Chalet and entertainment in Predeal. The children were left with pleasant memories and the desire to repeat the experience. A Christian Tour guide has taught them the cherishing of nature and how important it is to "make friends" with her.

The actions on local community development of Eximtur have diversified in three directions: education, culture and sports. The environment will be introduced into the company's CSR 
concerns next year and they are pursuing actions that will lead to the protection and preservation of tourist attractions.

For education, Eximtur has been involved in supporting the CuGeT Olympics (Youth Culture General Youth Club of Cluj). Through the allocated budget, the local community is rewarded, "if you receive then give it back", a chain of positive values and sustainable development is created. They displayed active involvement in the "Adopt a Village" project, in which the company partnered alongside RBL (Romanian Business Leaders). The idea of the project is that 80,000 Romanians take the migration route annually, equivalent to 24 communes. The Adopt a Village project aims to work with 10 rural communities by offering specific learning sessions that highlight local products, cultural sights and cultural heritage in the Romanian village. Until now 3 villages have been adopted: Corbi, Valea Stanciului and Ghindaresti. The villages have been helped to capitalize on their tourism resources, to develop their gastronomic, tissue, pottery, etc. talents. Eximtur intervenes financially to support these communities, but especially creates tourism packages that include the adopted villages. It is reorienting the flows of foreign tourists to the villages, giving them rural experiences: taking part in the village's dances, serving various local dishes (fish soup, polenta, etc.). The role of the travel agency is to bring tourists to these rural areas, the villages becoming reference points on the map of tourist circuits for Romanians and foreigners. All tourists are impressed by rural beauty and untouched nature. Tourists look for areas where man has not intervened in the transformation of nature and find them in Romania with the help of travel agencies.

Sport - because it makes you an organized, disciplined, ambitious, determined per-son - has been a basic concern for Eximtur, which is the sponsor of the women's basketball team and the men's basketball team of Cluj, participates annually at marathons, together with Eximtur employees through strong financial and human involvement.

As far as the communities that represent tourist destinations are concerned, the criteria of sustainable tourism are not considered distinctly and explicitly. By implication, the inclusion of certain destinations in the packages is a contribution to local economic development, as is the case with the recruitment and training of local staff or collaborators, or by contracting services with local entrepreneurs. A notable example is the recruitment and training of guides, which are an important pre-occupation for each tour operator. Christian Tour has even set up a school of guides called "Christian Adventure". Since compliance with local laws, regulations and regulations is systematically ensured, possible problems are related to excessive tourism (see the case of Venice) as well as destinations in some "weak governance (OECD) countries". It is clear from the interlocutors that tour operators reject any form of violation of internationally accepted rules on human rights, discrimination, exploitation and harassment, as well as the fact that in their relations with local partners they promote the principles of equal opportunities and decent work. Also, the interlocutors are unaware of the existence of cases of deviation from these rules which they have observed directly or which have been reported to them by tourists or by other means.

GSTC Section C - Maximize benefits to cultural heritage and minimize negative impacts

The third set of criteria for sustainable tourism refers to the policies, procedures and measures which tour operators have to implement for capitalizing on and preserving cultural heritage. Since the knowledge of local cultural heritage is an objective and motivation for tourism, the appreciation of the cultural heritage in the visited areas represents a valuable component from 
the design of the tourist offer. From this point of view, the business interests and the social responsibility of the tour operators merge perfectly. From the perspective of protecting and preserving the cultural heritage and tourist sites, the interlocutors considered it a public responsibility. "Abroad, tourist taxes are used transparently to restore historic objectives, preserve tourist sites, protect cultural attractions, and invest in monument preservation projects. In Romania this is not happening ", and it is a bad thing in the opinion of the tour operators interviewed. Everyone has mentioned this aspect of their active interest in preserving cultural attractions, which in turn would not affect vacation packages made and sold by tour operators.

All three tour operators systematically identify and include in tourism packages the visit of monuments, museums and memorial houses, actions to familiarize with local traditions, participation in cultural events. A particular concern is to promote the culi-nary specifics of the visited areas.

Interlocutors highlight the role of tourism programs in rural areas in promoting re-sponsible tourism and preserving tourist sites. The "Senior Voyage" programs pro-moted and produced by Christian Tour are held in Bucovina, Mărginimea Sibiului, etc. and they are designed in such a way that tourists enjoy the beauty of nature, but at the same time to get to know the cultural traditions (they can go to Mocăniţa in Maramureş, or they can participate in the night of Sânziene at Şirnea). Tourists have been extremely receptive and have said that they will also pay particular attention to cultural heritage in the future.

Regarding the potential negative impact of tourists' actions on historic remains and other cultural heritage features, tour operators ensure that tourists know the rules and good practices, and tour operators and local collaborators are trained to watch over the behaviour of tourists to prevent deviant acts.

GSTC Section D - Maximize benefits to the environment and minimize negative impacts

The GSTC Section D criteria refer to policies and measures of tour operators aimed at preserving resources, reducing pollution, preserving biodiversity, ecosystems and landscapes.

Internally, each tour operator is engaged in paper and printer recycling and copier projects, the volume being significant. Also, in the construction of new headquarters and the modernization of the old ones, solutions are chosen which aim to reduce the energy and water consumption.

A specific element of tourism activity with significant impact on the environment is transportation. The coaches that Paralela 45 uses must meet Euro 5 standards and have low NOx emissions. The company's representative acknowledges, however, that the choice of transport service providers is to prioritize the safety and comfort of the passenger, and only then to reduce pollution. Instead, Christian Tour, which has its own fleet of coaches Memento Bus - proposes renewing the car park with eco cars and phasing out fuel-based coaches. The Memento Bus fleet is gradually renewing with electric cars by the end of 2018 . It is working intensely on this Eco Bus buses project because it is a clean, silent and secure transport. Through this development project, Christian Tour wants an active involvement in protecting the environment. By the end of 2018, the first cars will be purchased. Eco buses are more expensive, but the long-term agency thinks it's worth the whole investment. For the 
circuits abroad, the infrastructure required for Eco Machines is performing well. For Romania, sustained efforts are being made to succeed in introducing eco-machines and power stations. Eco machines want to be bought through a state-subsidized project.

Tour operators are actively involved in environmental protection through their projects. Their strategies start from the motto "we can all be educated" to protect the environment. In bus and coach circuits in the country and abroad, tourists are advised to collect the garbage in a bag and the plastic bottles in a different bag and be brought forward, near the driver and guide. They will recycle the garbage in the arranged places. Tourists are attracted to being responsible for the garbage they produce.

Lately, there has been an increase in the interest of wildlife customers, areas closer to nature, and agencies come at the request of customers with packages in these areas. Travel consultations make documentation on these nature reserve destinations and offer all the information they need to the tourist. Travel agents inform tourists about existing recycling rules in the places that tourists are about to visit, and attract the agency to details on environmental protection, the use of biodegradable materials.

All operators have performance schools for tour guides who are actively involved in educating the tourist about the conservation of nature's biodiversity. We mention here: The Guides School - Christian Adventure, an integral part of the Christian Tour that offers free practical and theoretical courses of guides, the Eximtur School of Tourism offering travel agent and travel guides with more than 600 graduates, of the three now employed Eximtur, Guides Parallel 45, with hundreds of guided tours and positive feedback.

An important part of the Senior Voyage packages is to spend their holidays in a natural environment and with a special respect for nature. Thus, an important component in the Senior Voyage packages is respect for nature. The TO experience shows that seniors are more respectful of nature than young people. Education starts when we are young and so Christian Tour informs tourists of the importance of respect for nature. Both young and seniors are educated by TO Christian Tour to take care of nature. At the year 2017, 14,000 tourists chose to travel with Senior Voyage, the tour operator contributing to their awareness of the importance of nature conservation.

To help raise awareness of the importance of reducing greenhouse pollution and preserving green areas even in crowded towns, Paralela 45 has proposed a clean-up project in Bucharest, along with employees to be deployed later this year.

\section{Conclusions}

Following in-depth interviews with representatives of three of the most important Romanian tour operators, there was a constant and genuine concern for incorporating the principles of social responsibility into the management of those organizations, into strategies, plans and programs. By conducting interviews on the structure of the GTSC Tour Operators Criteria, each of the representatives of the three companies could present concrete elements proving the existence of projects, initiatives and actions targeting all the major themes of sustainable tourism. In the opinion of the authors of the present study, the organizations concerned have reached a certain maturity in terms of social responsibility and are ready to move to the implementation of an internationally certified sustainable tourism system. Such a goal 
implies a long-term commitment and the allocation of significant resources including financial.

In general, the issue of social responsibility is attributed to marketing directors, being recognized that the main motivation of social responsibility policies is to strengthen corporate image and achieve more favourable positions in customer preferences. However, the representatives of the three organizations appreciate that there is no pressure from customers for products and services that are recognized as sustainable. As such, although they do not exclude for the future that their firms are proposing to obtain certification for sustainable tourism, this is not a priority for the present.

The social responsibility policy is focused on its own organization and targets to a lesser extent the other links of the supply chain. There is no institutionalized obligation to verify to what extent providers whose services are included in packages offered to tourists complies or violate internationally recognized rules of sustainable tourism, nor the practice of giving priority to providers with superior sustainability performance. There are, however, a number of consumer education initiatives on the one hand, and the development of certain destinations with benefits for local communities and for cultural heritage. Hence, it will not be very difficult for these organizations to take the next step towards codifying their own sustainable development policies.

The environment issue is found in tour operator concerns more in terms of attraction elements and of the health and safety of tourists, and to a lesser extent with respect to biodiversity conservation, ecosystem protection and the promotion of bioeconomic productive solutions. It is right that the relationship of tourism with these latter aspects is mediated by the Sustainable Management of Tourist Destinations, a relatively recent concept, the implementation of which lies mainly with the local communities. Tour operators could help by informing tourists, promoting more intensively, and prioritizing sustainable destinations in tourist packages.

It should be noted that the three tour operators included in the study were self-selected precisely because of a greater interest in the issue of social responsibility and sustainable tourism. These are big companies with good market reputation, important financial resources and stability. This justifies the appreciation that, among Romanian tour operators, they are also the most advanced on the path towards compliance with the requirements of sustainable tourism. They can represent a model for other industry organizations and can assume a leadership of transition to sustainable tourism with potential benefits for their own businesses. Such a transition can only be successful with the support of coherent, consistent and consistent public policies, and with the involvement of a variety of stakeholders, with universities and other institutions in the education sphere being important contributors.

\section{References}

Anselmsson, J. and Johansson, U., 2007. Corporate social responsibility and the positioning of grocery brands: an exploratory study of retailer and manufacturer brands at point of purchase. International Journal of Retail \& Distribution Management, 10, p.849.

Antošová, M., 2015. Influence of European Union Policy to Corporate Social Responsibility. Procedia Economics and Finance, 23, pp. 733-737. 
Bristow, R.S., 2013. Factors Influencing a Business Preference for Tourism Sustainability: An International Example. In: SUNY College of Environmental science and Forestry, The 2013 Northeastern Recreation Research Symposium. New York, USA, April 7-9 2013. [online] Available at: <https://scholarworks.umass.edu/nerr/2013/> [Accessed 15 August 2018]

Budeanu, A., 2005. Impacts and Responsibilities for Sustainable Tourism: A Tour Operator's Perspective. Journal of Cleaner Production, 13, pp.89-97.

Bugge, M. M., Hansen, T. and Klitkou, A., 2016. What is the Bioeconomy? A Review of the Literature. Sustainability, 8(7), [691]. https://doi.org/10.3390/su8070691

Butowski, L., 2012. Sustainable Tourism - A Model Approach. INTECH Open Access Publisher. London, UK. [online] Available at: <https://www.intechopen.com/books/ visions-for-global-tourism-industry-creating-and-sustaining-competitive-strategies/ sustainable-tourism-a-modeling-approach> [Accessed 29 July 2018]

Carey, S., Gountas, Y. and Gilbert, D., 1997. Tour Operators and Destination Sustainability. Tourism Management, 18, pp. 425-431.

Coles, T., Fenclova, E. and Dinan, C., 2013. Tourism and corporate social responsibility: A critical review and research agenda. Tourism Management Perspectives, 6, pp.122-141

Craciun, M., 2016. CSR în România: cele mai responsabile companii multinaționale. [online] Available at : <http://www.thetrends.ro/csr-in-romania-cele-mai-responsabile-companiimultinationale/> [Accessed 3 March 2018].

Dahlsrud, A., 2008. How Corporate Social Responsibility is Defined: an Analysis of 37 Definitions. Corporate Social Responsibility and Environmental Management, 15, pp.:1-13

Edgell, D.L. Sr., 2016. Managing Sustainable Tourism: A Legacy for the Future. 2nd. New York: Routledge.

European Commission, 2011.Communication from the Commission to the European Parliament, the Council, the European economic and social Committee and the Committee of the regions a renewed EU strategy 2011-14 for corporate social responsibility, Brussels

Global Sustainable Tourism Council, 2016. Global Sustainable Tourism Criteria for Hotels and Tour Operators. [online] Available at: <https://www.gstcouncil.org/gstccriteria/gstc-industry-criteria-for-hotels/> [Accessed 3 March 2018].

Goffi, G., Masiero, L. and Pencarelli, T., 2018. Rethinking sustainability in the tour-operating industry: Worldwide survey of current attitudes and behaviours. Journal of Cleaner Production, 183, pp. 172-182

Holloway, J.Ch., 2012. The business of tourism. 9th ed. Harlow: Pearson.

Inoue, Y. and Seoki, L., 2011. Effects of different dimensions of corporate social responsibility on corporate financial performance in tourism-related industries. Tourism Management, 32, pp.790-804

Jiran, H. and Reber, B.H., 2011. Dimensions of disclosures: Corporate social responsibility (CSR) reporting by media companies. Public Relations Review, 37(2), pp.166-168

Jucan, C.N. and Dolf Baier, M.S., 2012. The ICT Implication on CSR in the Tourism of Emerging Markets. Procedia Economics and Finance, 3, pp.702-709

Kalisch, A., 2002. Corporate Futures: Social Responsibility in the Tourism Industry. London: Tourism Concern.

Levy, S.E. and Park, S.Y., 2011. An Analysis of CSR Activities in the Lodging Industry. Journal of Hospitality and Tourism Management, 18(1), pp.147-154 
Marin-Pantelescu, A., 2009. Diversificarea și personalizarea serviciilor turistice $\hat{\imath}$ contextual globalizării. Bucharest: ASE Publishing.

Miller, G., 2001. Corporate Responsibility in the UK Tourism Industry. Tourism Management, 22, pp.589-98.

Mobin, F., Zillur, R. and Khan, I., 2016. Measuring consumer perception of CSR in tourism industry: Scale development and validation. Journal of Hospitality and Tourism Management, 27, pp.39-48

OECD, 2018. OECD Tourism Trends and Policies 2018, OECD Publishing, Paris, http://dx.doi.org/10.1787/tour-2018-en

Power, S., Di Domenico, M.L. and Miller, G., 2017. The nature of ethical entrepreneurship in tourism. Annals of Tourism Research, 65, pp.36-48

Sheldon, P. and Park, S.Y., 2011. An Exploratory Study of Corporate Social Responsibility in the U.S. Travel Industry. Journal of Travel Research, 50(4), pp.392-407

Spenceley, A. ed., 2012. Responsible tourism: critical issues for conservation and development. London: Earthscan.

Supanti, D. and Butcher, K., 2018. Is corporate social responsibility (CSR) participation the pathway to foster meaningful work and helping behaviour for millennials? International Journal of Hospitality Management, [e-journal] 10.1016/j.ijhm.2018.06.001

Tapper, R. and Font, X., 2004. Tourism Supply Chains. Report of a desk research project for Travel Fundation. [online] Available at: <https://www.slideshare.net/

TheSupplychainniche/tourism-supply-chains?utm_source=slideshow02\&utm_medium= ssemail\&utm_campaign=share_slideshow_loggedout $>$ [Accessed 15 February 2019]

Tepelus, C.M., 2005. Aiming for Sustainability in the Tour Operating Business. Journal of Cleaner Production, 13, pp.99-107.

Theodoulidis, B., Diaz, D., Crotto, F. and Rancati, E., 2017. Exploring corporate social responsibility and financial performance through stakeholder, theory in the tourism industries. Tourism Management, 62, pp.173-188

Tschopp, D., 2005. Corporate Social Responsibility: A Comparison Between the United States and the European Union. Corporate Social Responsibility and Environmental Management, 12, pp.55-59

Van Wijk, J. and Persoon, W., 2006. A Long-Haul Destination:Sustainability Reporting among Tour Operators. European Management Journal, 24, pp.381-95

Wearne, N. and Baker, K., 2002. Hospitality Markiting in the e-commerce Age. 2nd ed. Australia: Hospitality Press.

Wells, V.K., Manika, D., Gregory-Smith, D., Babak, T. and McCowlen, C., 2015. Heritage tourism, CSR and the role of employee environmental behaviour. Tourism Management, 48, pp.399-413

Wells, V.K., Gregory Smith, D., Babak, T., Manika, D. and McCowlen, C., 2016. An exploration of CSR development in heritage tourism. Annals of Tourism Research, 58, pp. 1-17

World Travel \& Tourism Council, 2019. Travel \& Tourism Economic Impact 2018. [online] Available at: <https://www.wttc.org/-/media/files/reports/economic-impact-research/ regions-2019/world2019.pdf > [Accessed 31 March 2019]

Yilmazdogan, O.C., Secilmis, C. and Cicek, D., 2015. The Effect of Corporate Social Responsibility (CSR) Perception on Tourism Students' Intention to Work in Sector. Procedia Economics and Finance, 23, pp.1340-1346 